\title{
A Survey on Interior Textiles at İzmir Atatürk House Museum
}

\section{İzmir Atatürk Evi Müzesi'ndeki İç Mekân Tekstiller Üzerine Bir Araştırma}

Tülay Gümüşer, Department of Shoe Design and Production, Selçuk University

\section{Abstract}

This study deals with the interior textiles of the house that Mustafa Kemal Atatürk, the founder of the Republic of Turkey, used as headquarters and resided for a short period of time. Interior textiles in the house museum provide a useful framework for understanding how home culture was shaped, experienced, and imagined in that period. Interior textiles in a house museum provide a rich source for researchers to get background information. These textiles can be original, non-original or replicas. During the research, it was found out that the original upholstery fabrics were replaced with the fabrics that did not match with the original ones as a result of the restoration of Atatürk House Museum. For this reason, the research was carried out with the non-original textiles. Here, the critical question is "Do the non-original textiles fail to reflect the spirit of a nation or a personal taste?". This study investigates the connection between the nonoriginal textiles and the early republic period. Within the scope of the research, the researcher has interpreted the design features and upholstery fabrics of one armchair, one sofa and three chairs, which stand in the drawing room, bedroom, dining hall and meeting hall.

Keywords: Atatürk House Museum, interior textiles, upholstery fabrics.

Academical disciplines/fields: Interior textiles, textile design, museum houses.

\section{Özet}

Çalışmada, Türkiye Cumhuriyeti'nin kurucusu Mustafa Kemal Atatürk'ün karargâh olarak kullandığı ve kısa süreli ikamet ettiği evin iç mekân tekstilleri ele alınmaktadır. Bir müze evin iç mekân tekstilleri ev kültürünün nasıl şekillendiğini, deneyimlendiğini ve o dönemin ruhunu nasıl yansıttığını anlamada faydalı bir çerçeve sunmaktadır. Müze evin iç mekân tekstilleri, geçmișe ait bilgiler elde etmek için araştırmacılara zengin kaynak sunarlar. Bu tekstiller; orijinal, orijinal olmayan veya replika olabilirler. Çalışmanın araştırma sürecinde, Atatürk Müze Evi'nin restorasyon sonrasında döșemelik kumașların orijinaline uygun olmayan kumașlarla değiştirildiği tespit edilmiştir. $\mathrm{Bu}$ nedenle, araştırmaya orijinal olmayan tekstiller üzerinden devam edilmiștir. Calıșmada, orijinal olmayan tekstiller bir ulusun ruhunu ya da kişisel zevklerini yansıtır mı? sorusundan yola çıkılarak orijinal olmayan iç mekân tekstillerin erken Cumhuriyet Dönemi ile bağı araştırılmıștır. Araştırma kapsamında, misafir odası, yatak odası, yemek salonu ve toplantı salonunda bulunan bir koltuk, bir sofa, üç adet sandalyenin döșemelik kumașlarının tasarım özellikleri yazar tarafından yorumlanmıștır.

Anahtar Sözcükler: Atatürk Evi Müzesi, iç mekân tekstiller, döșemelik kumașlar.

Akademik disipin(ler)/alan(lar): İç mekân tekstiller, tekstil tasarım, müze evler.

- Corresponding Author: Tülay Gümüșer, Faculty of Architecture and Design, Selçuk University

- Address: Selçuk Üniversitesi, Mimarlık ve Tasarım Fakültesi, Alaeddin Keykubat Yerleşkesi, Konya, Türkiye

- $\quad$ e-mail: tulaygumuser@gmail.com

- ORCID: 0000-0002-6264-2629

- Available online: 04.06 .2021

- doi: $10.17484 /$ yedi.842825 


\section{Introduction: From House to House Museum}

\subsection{House Museum in Turkey}

The major deconstruction will be the isolation of the term house from the term museum. The term house may be defined as the physical space in which the private human habitation takes place (Bennet, 1995, p. 41), or can only be interpreted with respect to certain concepts like personal memory and remembrance (Hansson, 2007, p. 4). The term museum, on the other hand, is used to define an institution in which historical objects and cultural interests are displayed, and the related information is made accessible. $A$ more functional definition of a house museum is to say that it is a dwelling, museumized and presented as a dwelling (Young, 2007, p. 60). Historic House Museums, as a new museum type, were first appreciated in Europe when DemHist (Demeures Historiques--Musées/Residencias Històricas-Museo) was established in Genova in 1997. DemHist as an International Committee of the Council of Museums (ICOM) declared house museums as a new research field in museology, identifying their historical, artistic, cultural, and social aspects. This committee aimed at creating a system, as one of its first projects, for classifying the historic house museums with a homogenous museological line. Giovanni Pinna, Rosanna Pavoni and Magaly Cabral are among the experts accepted as the authorities in this new field (Günhan, 2011, p. 9). Giovanni Pinna who is one of the founders of DemHist, defines historical house museums as:

Historic houses, when they are open to the public and conserved in their original condition (i.e. with the furnishing and collections made by the people who used to live in them) and have not been converted to accommodate the collections from different sources, constitute a museum category of a special and a rather kind. Historic house museums comply with museological and technical constraints that are different from those used in other museums. Their category is different because historical houses may comprise sites of all sizes and kinds, ranging from royal palaces to residences of powerful personages, artist's studios, rich bourgeois houses and even modest cottages. The historic house is certainly incomparable and unique museum in that it is used to conserve, exhibit or reconstruction real atmospheres which are difficult to manipulate (to very slight extent) if one does not wish to alter the meaning very of historic house. (2001, p. 4-9; Savaș, 2010, p. 146)

Depending on the explanations above, it can be questioned if a house museum is a historic house or not, or if a house museum is in a different category from historic houses or not". Stating that there is a difference between historic houses and house museums, Pinna adds that it is not true to treat it as a museum if a house with historical characteristics is protected as it is. Such a house has historical value. Therefore, it should be in the category of 'historic houses'. This is because there are huge differences between the historic houses and the houses converted into museums. While historic houses consist only of an original collection, house museums are those that accurately reflect the social and political experiences, as well as the original structure and the collection, and they reflect the past in an accurate way. House museums are places where visitors are provided with a suitable representation for museology (maintenance, repair, sales departments, security, marketing, etc.) (2001, p. 7).

After the meeting in Genova, Italy; a similar attempt for the institutionalization of the house museums in Turkey was made with a symposium in Ankara, Turkey. House Museums/Historic Houses International Symposium 1 was held on the June 11st, 2010. The house museum founders, owners and directors, and the academics focused on this issue were the delegates and the collaborates of the symposium. Rosanna Pavoni, the president of DemHist, was the keynote speaker at the symposium. The aim was to create an awareness of the house museums in Turkey, to initiate an institutionalization process and to assemble a group of authorized people for further development in the subject matter (Günhan, 2011, p. 13). With this attempt raising an awareness, a formal house museums committee was established for the appreciation and institutionalization of the house museums in Turkey and an inventory of house museums was created (Günhan, 2011, p. 13-14).

How are the house museums, which have been discussed on international platforms recently, defined in Turkey? While Professor Sümer Atasoy describes house museums as "the structures that should be protected because of its architecture and the person living in it" (Madran, 1999, p. 14), Dr. Mehmet Önder, a leading researcher on museums, describes house museums as mansions and houses that should be protected in historical and architectural aspects (Madran, 1999, p. 14). Considering these definitions, it is 
understood that house museums are one of the few houses with a certain architectural feature, besides reflecting a historical period or a historical figure. Many houses, mansions, and pavilions in various cities of our country have been converted into museums due to its regional characteristics, or because it belongs to an important person (Uz, 2015, p. 272). Most of the houses in which Atatürk lived or set up as his headquarters are now open to the public as a museum. Atatürk House Museum is important in that it witnessed the Republican period besides having an architectural value (Savaș, 2010, p. 145). The houses at which Atatürk worked with his friends in the processes of the struggle for liberation, held meetings, took historical decisions about the future of a nation and stayed as a guest during his regional trips after the foundation of the Republic of Turkey are the places that were changed into the monuments with historical memories of Atatürk (Koşan, 1981, p. 1). As such, it is clear that Atatürk Houses would have different functions. Accordingly, two of the existing Atatürk Houses were used for headquarters, six of them as headquarters-residences, two of them as administrative buildings, two of them as congress buildingsresidences, two of them as administrative buildings-residences and thirty-eight of them for residency only (Aliağaoğlu and Temurçin, 2004, p. 125). Today, the furniture in some of the houses which were converted into museums have been renovated depending on its original form while some of them have been kept unchanged.

Textiles are probably the most vulnerable items of any interior design and therefore most likely to be replaced (Ponsonby, 2011, p. 200). Interior textiles are produced for either the domestic (also referred to as private or residential) or 'contract' (also referred to as 'commercial') markets. Domestic textiles are those found in the houses or private interiors. Interior textiles are usually discussed in relation to two key categories: furnishing fabrics and household textiles. Furnishing fabrics are: upholstery fabrics, soft floor coverings, carpets, wall coverings, window furnishing (curtains, drapes, blinds) and accessories such as cushions and throws (Yeager and Teter-Justice, 2000, p. 5). All these textiles carry the traces of the person's life, who lived there. We can regard these textiles as 'memory objects'. Memory objects are special objects or personal belongings that elicit deliberate or involuntary memories of homeland, home culture, important places, episodes in one's own autobiographical past and significant social relations (friends, colleagues) associated with home or origin (Marschall, 2019, p. 2). In his writing Death, Memory and The Life of Objects, Christian Boltanski (2019) states that when he works on the items left behind by a deceased person (who once lived in that house), he can understand the way s/he uses the items and make a connection with that lifeless body. As Boltanski points out, those objects tell a story. These are object cultures and information cultures for that person. It is because the deceased person chose, liked, and used those objects. Making a research on these objects is like unearthing them.

A phenomenon all throughout Turkey is that the buildings Atatürk used when he was alive have been changed into the museums frozen at the moment of his visit or stay. It is possible to visit these museums, where the collections of various objects and interior textiles of anytime between 1919 and 1938 are preserved and displayed, in both big cities such as Istanbul, Ankara and İzmir, and also in smaller towns and provincial capitals, especially those associated with the Turkish War of Independence, such as Samsun, Erzurum and Sivas (Wilson, 2007, p. 165). The Atatürk House Museum in İzmir, one of the most important harbor cities with its commercial activities and cosmopolitan structure in the Ottoman Era, is one of the above-cited museums with both the political importance, architecture, objects, and interior textiles in it.

In Turkish museology literature, there seems to be very little reference to the Atatürk House Museum in İzmir. The first study we have encountered in the literature is The figured Tiles and a Fireplace as Furniture Accessories in İzmir Atatürk House Museum by Lale Doğaner and Esen Soydan (2005), and Comparing the Cicim Samples Found in İzmir Atatürk House Museum by Öznur Aydın and Esra Kavcı (2005). The last study is Conversation and Repair Work for the Fireplaces in Izzmir Atatürk House Museum, which belongs to A. Sultan Karaoğlu (2011). In two of the studies mentioned, fireplaces and figured chairs have been examined in terms of the ceramic design. In the other one, the motifs on the rugs of the museum storage have been analyzed. However, there is no study carried out on the upholstery fabrics. This paper aims to fill this gap in historical literature in line with İzmir Atatürk House Museum which belong to the early Republic period. Working with interior textiles or objects in a museum takes the researcher on many unexpected journeys through the past. The journey in this research starts primarily with two questions: How did the transformation of interior textiles take place from the period of the Empire to the Republic? Do the interior textiles in the Early Republic Period (1923-1950) reflect the national identity?

When Atatürk House Museum was visited to get some answers to these questions, it was discovered that not all the interior textiles are original. As a result of the meeting with the museum art historian, it was found out that that historic house was converted into a museum in 1941 after Atatürk's death in 1938. The transformation occurred in accordance with the original and without any modification, including Atatürk's 
personal belongings. After the restoration of the museum, the textiles were replaced with the fabrics that are not like the original ones. The original fabrics were not preserved, restored and registered. This result once again reveals the importance of the archive and preservation culture. On the other hand, many methods were also being implemented at that time for maintenance, repair, storage and display conditions of every artifact and object in the museum (Atasoy, 1999, p. 16). It is because museums are related to the past events and the materials used at that time (Sönmez, 1994, p. 101). As seen in this example, there is a steady state in Turkey and the community-museum dialogue has not been established yet (Genim, 1994, p. 16). The fact that there are not enough publications made in our country proves this situation. This result has once again demonstrated the importance of restoration and made us think about the following questions: What should a house museum be like? and How should the textiles here be protected? This unexpected discovery has changed the way in which the research will be carried out (taking into account the questions above). By readdressing the focus on textiles in the Atatürk House Museum's interiors, the aim of this paper is to highlight the matter originality, non-originality or re-production/replica.

\section{Methodology}

This research has been conducted with the case study method. Case study research, through the reports of the past studies, allows the exploration and understanding of complex issues (Zainal, 2007, p. 1). It is a qualitative approach (Creswell, Hanson, Clark Plano and Morales, 2007) in which the chosen case should be specific and complex in order for it to be unique (Merriam, 1998; Shuang and Lee, 2020, p. 83; Stake, 1995). This study is based on the content analysis of the information obtained from the literature, the museum's archive records, the interview with the museum's staff and the visit to the museum on February 21-28, 2019 for the purpose of experiencing the atmosphere personally and analyzing more specifically how the textilebased objects relate to this atmosphere. The research permit has been approved by the Provincial Directorate of Culture and Tourism, İzmir Governorship and İzmir Archeological Museum Directorate. While the research was originally planned as an examination of the pattern designs of the interior textiles in the museum, the direction and scope of the research changed because it was learned that the fabrics to be examined were not original. There is no reproduction/replica of the original upholstery fabrics because the original fabrics have not been photographed or recorded since the first restoration of the house museum (1940). Due to the fact that there are no original or replica fabrics in the museum, the fabrics examined in this article are described as non-original. Since textile is a discipline which requires a comprehensive research in itself, this study is limited only to the upholstery fabrics in the museum. In addition, this study does not comparatively examine the indoor textiles in the museum houses and it is limited only to Atatürk House Museum in İzmir province independently of other provinces. The other Atatürk House Museums, located in many different provinces in Turkey, have been excluded from this study because they require a further research. In this context, the study addresses the following questions:

Do the non-original textiles influence the spirit of national or personal taste?

What were the interior textiles in the early Republic period be like?

The patterns of interior textiles (motif, color, texture, design composition and technique) will be evaluated in order to find an answer to these questions.

\section{Interior Design as a Practice of Modernity}

\subsection{Re-creation of a New Style in the Early Days of the Republic of Turkey}

The Turkish society went through a series of Westernization and modernization reforms along with the dramatic changes in the early 20th century, when the Republic of Turkey was founded by Mustafa Kemal Atatürk (Bici Nasir, Timur and Gürel, 2020). The reforms were aimed at bringing the new Republic system away from the effects of the Ottoman Empire (Bozdoğan, 2001). Two opposing practices - the one associated with the Islamic, Ottoman, traditional and local persuasions and the other one associated with the Western, global and modern values - influenced and structured the cultural stratification of the upper classes and the middle classes in Turkey. The furniture and decoration units of the interiors in the new Republic were much different than the traditional Ottoman settings. Such furniture as dining tables, chairs, armchairs and couches, which were ostentatious, immobile and heavy, replaced the basic traditional furniture such as the floor tables and the cushions (Bici Nasir, Timur and Gürel, 2020). Gökhan Karakuş called the modernist design of Turkish furniture as "handmade modernism, which is because there were no manufacturing technologies for the industrial materials (steel, glass or synthetic materials) in the country. 
Modern architecture and furniture design are the concepts which gained importance with the Republican reforms in the 1930s" (2010, p. 123). the logical changes in the West during the 1920s were not parallel to the Turkish war of independence between 1919 and 1923. 'Privation', which was one of the social stimuli for Art Deco under the Haslam, was not heard at that time in Turkey. After the foundation of the Republic in 1923, the Turkish economic policy, like that of many other states during the Great Depression period, became protectionist. However, Turkey uniquely experienced the modernization towards a new nation founded by Atatürk, which was ideologically formed of the combination of Western Capitalism and Soviet Socialism (Turan, 2010, p. 239). Both textiles and architecture reflected the personal, social, and cultural identity, with the concerns and ambitions of the users at that age (Kotb, 2014, p. 19).

Mustafa Kemal Atatürk, widely viewed as a role model for the nation, decorated his house with European furniture and created a modern style far from the baroque and classical luster of the former Ottoman palaces (Akcan, 2012). For example, Çankaya Mansion, or Atatürk Museum Mansion, was the residence of the President Atatürk in the early years of the Republic between 1921-1932. Atatürk Museum Mansion is one of the first places where we can see the modern approach to the interior designs in the Republic period. Atatürk Museum Mansion, which was decorated after 1924, has remained unchanged so far (Andaç Güzel and Efe, 2019, p. 4109). Selahattin Refik, who took an active role in the Republic period with his interior designs and modern applications, won Atatürk's appreciation, and his designs were effective during the first two decades of the Republic (Tosun and Özsu, 2014, p. 216). Selahattin Refik became the first practitioner of the modern approach to the furniture designs with very limited examples (Uras, 2003, p. 7). The fact that the original interior textiles were protected and archived is important for us to explain the of the early Republic period. As for the İzmir Atatürk House Museum, the restoration process was carried out in the same sensitivity as in the example of the Atatürk Museum Mansion. While all the furniture, clothes, and accessories, which belong to Atatürk, are displayed in their original form, the original interior textiles (upholstery fabrics, curtains, bed linings, and tablecloths) have been replaced with the non-original ones. When the literature in Turkey have been examined, it is possible to see that the house museums have generally been discussed in terms of their architecture or interior furniture. Although the domestic interior textiles are important, they are often neglected in the studies as to the historical house museums (Ponsonby, 2011, p. 200).

\section{2. İzmir Atatürk House Museum}

This house was built by Takfor, one of the major carpet traders in İzmir, probably in the last quarter of the XIX. century (1875-1880). It was named as Naim Palas Hotel for a period of time. The house was saved from being devastated during the liberation of İzmir on September 9th, 1922 and it has survived until today. This house is the place where Atatürk stayed when he visited İzmir and made many of his historical decisions since October 11th, 1925. The house has a Neo-classic style, which reflects the Ottoman and Levantine architectures. The house has a basement floor, a first floor, a second floor and an attic (Runner, 1981, p.8). There is a library and a meeting hall on the first floor of the main buildings. The other rooms have been transformed into the places where cultural and artistic activities, meetings and exhibitions are held and where Atatürk's principles and revolutions are told (Karaoğlu, 2011, p. 68). There is a bedroom, a dining room, a study room, a guest room, a guard room, barber room, and a bathroom upstairs. These rooms are furnished with interior textiles and home textiles. Among these are carpets, curtains, tablecloths, upholstery fabrics, bedclothes, pillowcases, and towels. According to the art historian of the museum, who was working there in 2019, this house museum was restored between 1962, 1972, 1978, 1999-2001. The upholstery fabrics were changed in 2001, when the Ministry of Culture carried out the restoration process. It has been stated that the fabrics came from Ankara and they were changed by the textile experts. In this process, unfortunately, there is not any record about which experts changed those fabrics.

There has always been a mutual organic bond between the textile and the place. Sometimes the place and the other times the textiles have come to the forefront (Dogan, 2019, p. 43). Susan Pearce stated in her paper Objects are the Heart of Museums that the objects and collections represent the base for the museums and their cultural missions (Hudales, 2010, p. 69). The textiles have an important role in creating the image that historical interiors portray, which depends on the color, tone or texture reflecting the neatness, tidiness, or shabbiness. Textiles are therefore so important to determine what we think about the historical interiors, how we see them, how we expect them to look, what we think a 'historical' interior is (Ponsonby, 2011, p. 200). Considering the explanations above, the following section will discuss whether the textiles in the house museum reflect the Republic period or the pre-Republic period, and also examples will be given about this issue. 


\section{Interior Textiles in House Museums: Upholstered Textiles and Aesthetic Characteristics}

With the foundation of the Turkish Republic in 1923, the country moved away from the traditional order grounded on Islam towards a Western and secular order with the new approaches in domestic settings (Bozdoğan, 2001; Gürel, 2007; Bici Nasir, Timur and Gürel, 2020). The halls and rooms became a means of reflecting a Western and modern identity. The original Art Deco designs, as an example of the modern approach to the interior designs, have an important position in the history of Turkish design (Tosun and Özsu, 2014, p. 217). As it is clear in the previous studies and information from the museum archive, all the furniture in the house museum has an Art Deco and Neo-classic style. Since the furniture has an Art Deco design, then it is likely for the upholstery fabrics to have an Art Deco style as well. However, this study will deal with the existing fabrics with their Art Deco styles because the samples of the fabrics have not reached the present day.

The Art Deco style between 1925 and 1930s included sunburst motifs, clear lines and such geometric forms as spheres, polygons, rectangles, trapezoids, zigzags and chevrons. These were often arranged in a symmetrical pattern (Kotb, 2014, p. 2). In the 1920s, early grayed, muted and soft colors were being used. The interior designs were in vivid colors. The most popular colors used at that time were red-violet, mauve, peach, gray-green, brown, rust, black and white, and gray and beige (Nielson, 2007, p. 424). Art Deco colors are generally rich, vibrant and vivid with high-contrast, silver or gold effects, and the metallic surfaces combined with softer hues are also used in this style (Kotb, 2014, p. 2). Art Deco is regarded as a harmonic and integrated composition of the contrast colors (Tosun and Özsu, 2014, p. 217). Silk fabrics with a bright color are the favorite materials in this style (Erdem, 2007, p. 78; Feryal, 2001). The stylized forms are symmetrical, the stylized floral motifs (Mülayim, 2017, p. 1015), are plain and elegant, and the fabrics are unpretentious.

In this part, four upholstered fabrics are prime objects. Since the fabrics could not survive for so long, they cannot be analyzed and it is very difficult to describe the original fabrics without any necessary data (archive records, photography or the original samples in the museum storage etc.). However, the pattern designs of the existing fabrics will be analyzed by taking into account the Art Deco style and the possible similarities and differences will be presented. As for the pattern design of the furnishing fabrics in the museum; Figure 1 shows the upholstered sofa (sedir or divan in Turkish) in Atatürk's bedroom. The sofa is covered by woven fabrics which was produced with the jacquard-loom. The olive-green parts of the fabric are filled with the floral motifs in gold and dark green. The composition schema of the fabric was repeated by full-drop system.

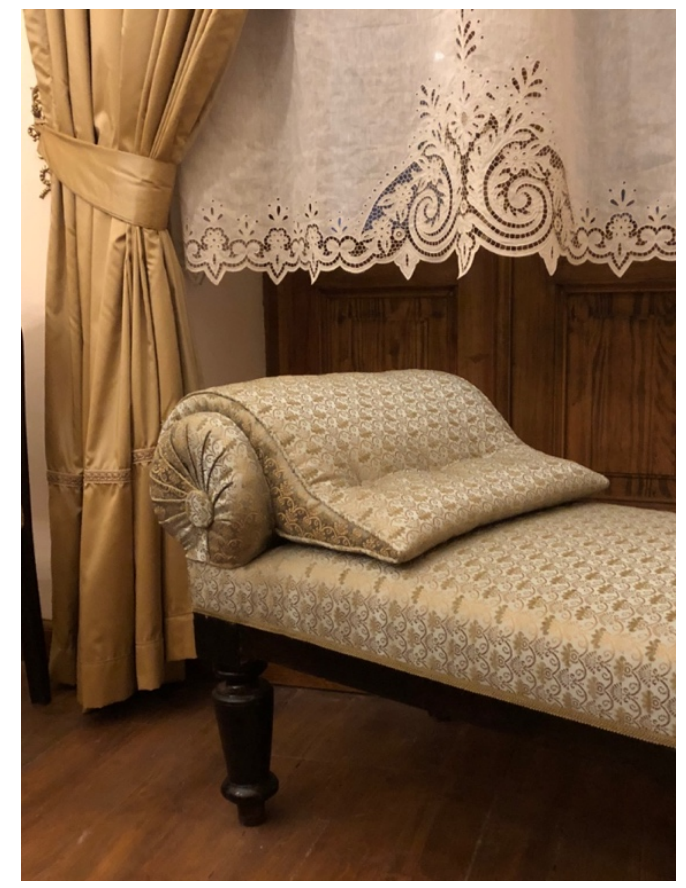

Figure 1. The Upholstered Sofa (2001) in Atatürk's Bedroom, Jacquard Weaving Technique, Photographed by the author (2019), Courtesy of İzmir Atatürk House Museum. 
According to the statements of the curator of the museum, all the furniture is in Art Deco style. The silver and gold colors on the upholstery fabric of this furniture matches with the Art Deco style of the period. As for the motifs, they do not match with the Art Deco style, which includes the flowers in large sizes and geometrical patterns. The small floral patterns on the fabric in figure 1 are similar to the jacquard silk weavings produced in Hereke Fabrika-i Hümayun / Hereke Factory (Yılmaz and Bosnak, 1999, p.25), which was established in the Ottoman Period in 1843 and now produces fabrics for the palaces, mansions and historical houses which are within the scope of the National Palaces. The motifs and colors used on the fabric are also similar to the ones on the visual examples in the Associate Professor Esra Kavci's extensive work titled Hereke Fabrics at Dolmabahçe Palace (2001) and Western Effect on the 19th-Century Ottoman Court Fabrics (2010). It is also known that the original patterns produced in the Hereke Factory were drawn by the Western artists. The patterns in the shape of $C$ and S 'Rococo style' should be considered as the geometrical patterns 'Neo-classic Style' (Yllmaz and Bosnak, 1999, p. 27). The Serenk fabric in 19th century, with its tricolor woven and small floral motifs are similar to the one shown in figure 1. The Ottomans were inspired by the Italian fabric patterns as a result of commercial relations with Italy; however, they preserved the authenticity in their fabrics with the weaving techniques that they used (Aslanapa, 2005, p. 363).

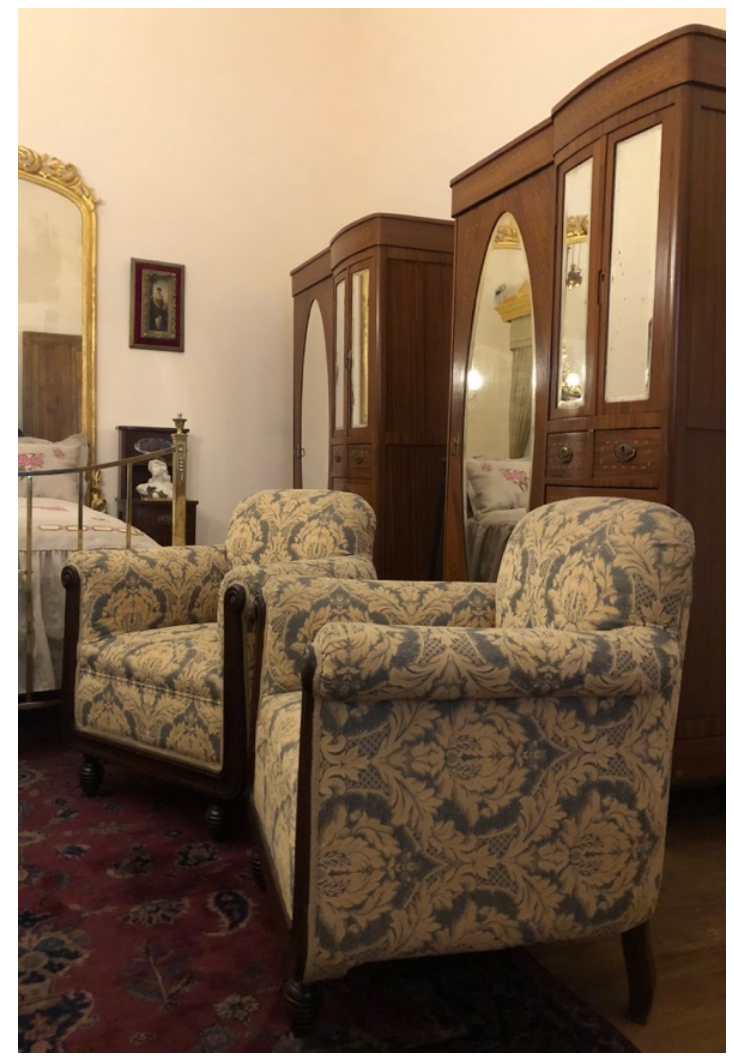

Figure 2. The Upholstered Armchair (2001) in Drawing Room, Jacquard Weaving Technique, Photographed by the author (2019), Courtesy of İzmir Atatürk House Museum.

The next sample, which is an upholstered armchair, is in the drawing room. There are the motifs of the cream-colored large floral crowns and the curved leaves on the blue colored surface. The surrounding contour of the curved leaves is grey. The composition has a design in a half-drop repeat system. There are the motifs filled in the large medallions. The pattern was woven into the fabric with a jacquard-loom, and the background was formed through a plain weave. It is possible to see that there is a Damask effect on the patterns of the upholstery in the (Fig. 2). Damask is a fabric formed through a plain weave with one set of warp threads and one set of weft threads (Hutton, 2004, p. 2). According to Webster International Dictionary, Damask is woven on a jacquard loom, the satin field being produced by float of warp that pass over from two to seven and in some intances nine filling. The design is a plain or taffeta weave, the warp and filling being at right angles that create less lustre than the satin area (Damask, 1966, p. 6). In other words, it is a reversible fabric, which is indigenous to Damascus, Syria. This beautiful patterned fabric has been created all over the world for nearly two thousand years (Mireles, 2010). Depending on these descriptions, it is not possible to say that the upholstery is Damask. The only thing that is clear is that the motifs of this sample is very similar to it. 


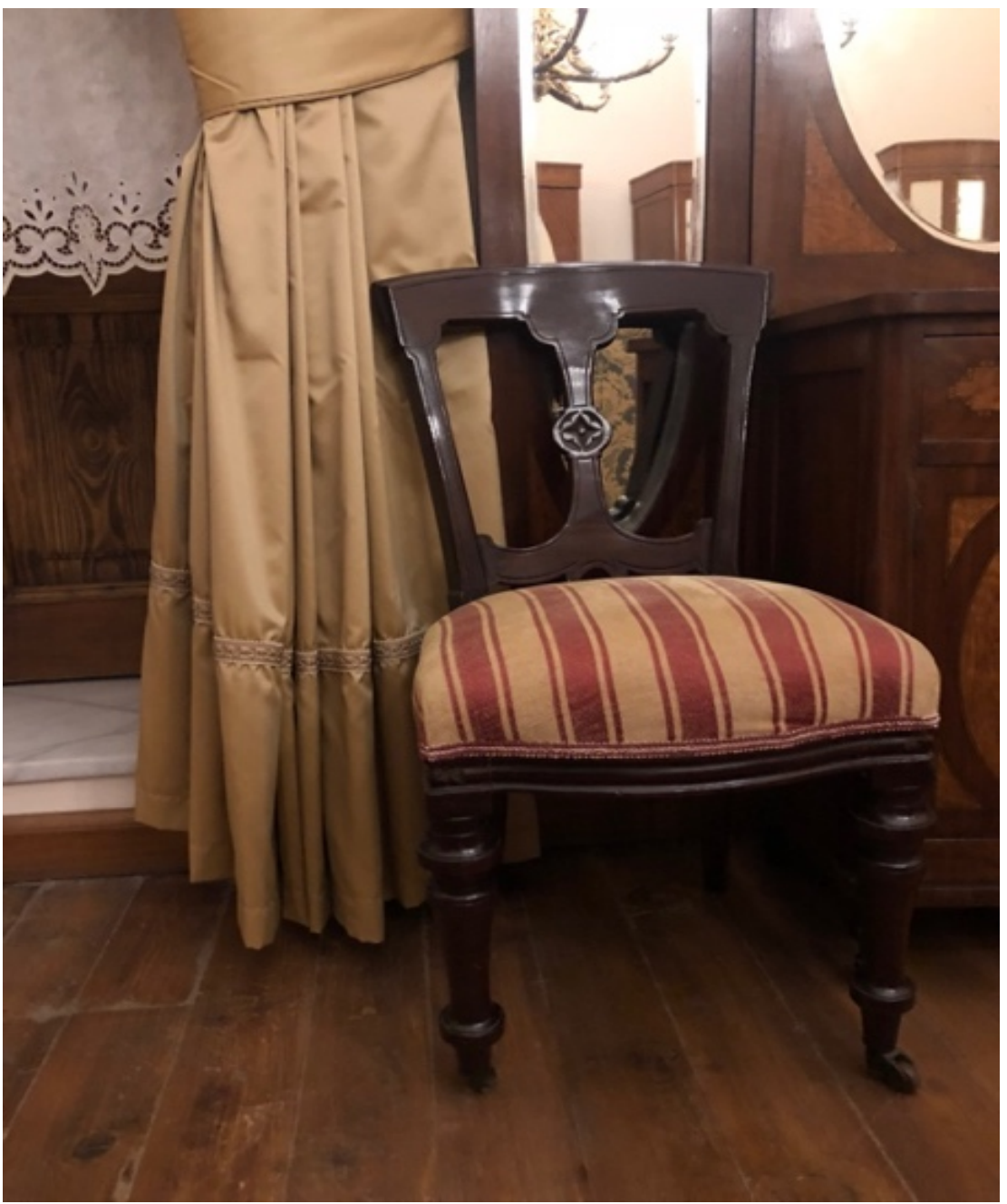

Figure 3. The Upholstered Chair (2001) in Drawing Room, Jacquard Weaving Technique, Photograph by author (2019), Courtesy of İzmir Atatürk House Museum.

Another example of the upholstered chairs is placed in the drawing room (Fig. 3). This upholstery has a twocolored fabric. The fabric of the chair has vertical stripes on it, it is covered with a cotton weft, and it probably has a silk or satin warp. There are the burgundy colored thick and thin vertical stripes on a creamcolored plain ground. The surface of the upholstery, which seems elegant, is similar to Kutnu, which was a very popular fabric both in the classical period of the Ottomans and then in the Republic of Turkey. As in the example, Kutnu is formed of longitudinal colored stripes, with a cotton weft and a silk warp (Gümüşer, 2018 , p. 597). There are also bright and flowery samples in addition to the ones with a plain weaving. 'Selimiye fabrics', which were produced especially during the period of Selim III (the Ottoman Period), have vertical/horizontal stripes as well as the small floral motifs. Kutnu was used as an upholstery fabric because it was thick and durable (Mutlu, Aydın and Hünerel, 2017, p. 95).

Figure 4 shows a similar figure to the flowery Selimiye fabric. The chair in the dining hall is covered with a two-colored fabric in figure 4 , which is very shiny like it is satin. The patterns consist of two-colored stripes. There is a plain weave on the side of the light green stripes while there are flowers and leaves on the side of the dark green stripes. The upholstery was designed with the use of the weaving techniques. Besides the Selimiye fabric, the design of this upholstery is also similar to the Sevai fabric, which were produced in İstanbul and date back to 18th century (Yetkin, 1993, p. 138). There are stylized leaves and flowers on the stripes of the Sevai fabrics. Sevai was weaved originally with silk and gold thread klaptan (Gümüșer, 2018, p. 222). However, the sample in the house museum is not weaved with gold thread due to financial problems these days. We can understand from these examples that there is a dramatic transformation in terms of the furnishing fabrics. 


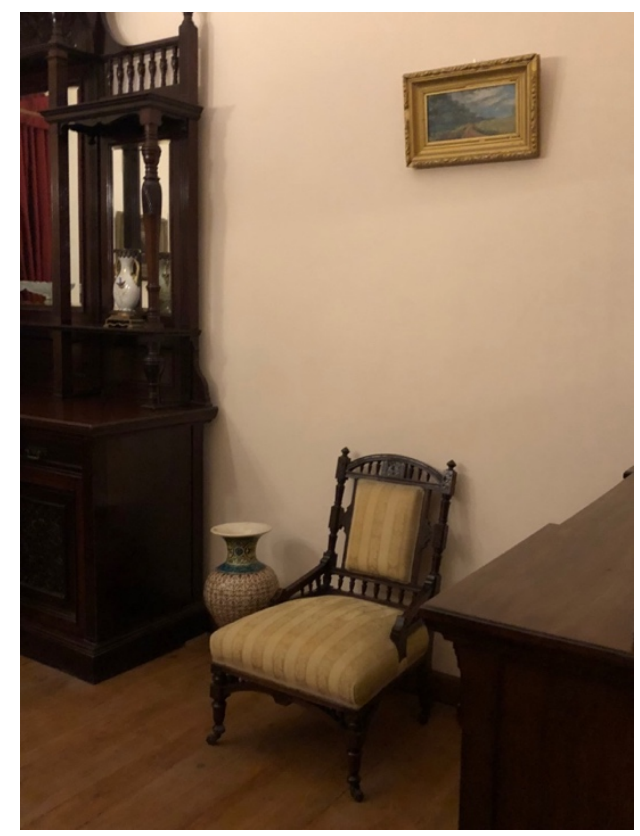

a)

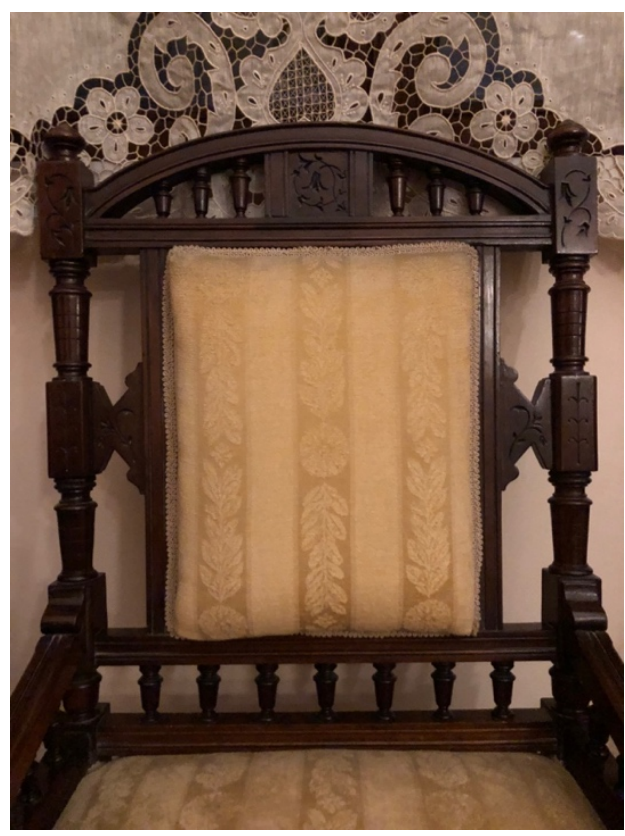

b)

Figure 4. a) The Upholstered Chair (2001) in the Dining Hall, Jacquard Weaving Technique, Photographed by the author (2019), Courtesy of İzmir Atatürk House Museum. b) The Upholstered Chair (2001) in the Dining Hall

Figure 5 shows the upholstered chair with the jacquard-woven fabric, which has a yellow-colored ground and crimson (the favorite color in Ottoman textiles) motifs in a half-drop repeat system. The ogival medallion motifs are surrounded with the serrated leaves, petals and stems. The ogival lattice provides a framework for the rows of the staggered leave motifs, petals and stems. The pattern of this fabric is similar to that of the brocade fabrics. Brocade is a rich and heavy jacquard-woven fabric with floral or figured patterns emphasized by contrast colors. Satin or twill figures may be used on twill, plain or satin grounds (Tortora and Johnson, 2013, p. 77). According to George Leland Hunter, brocades such as velvet and Damask are the aristocrats of the fabrics produced for the decoration of furniture. In fact, they are silk weaves, though often enriched with gold or cheapened with linen and cotton (1918, p. 5).

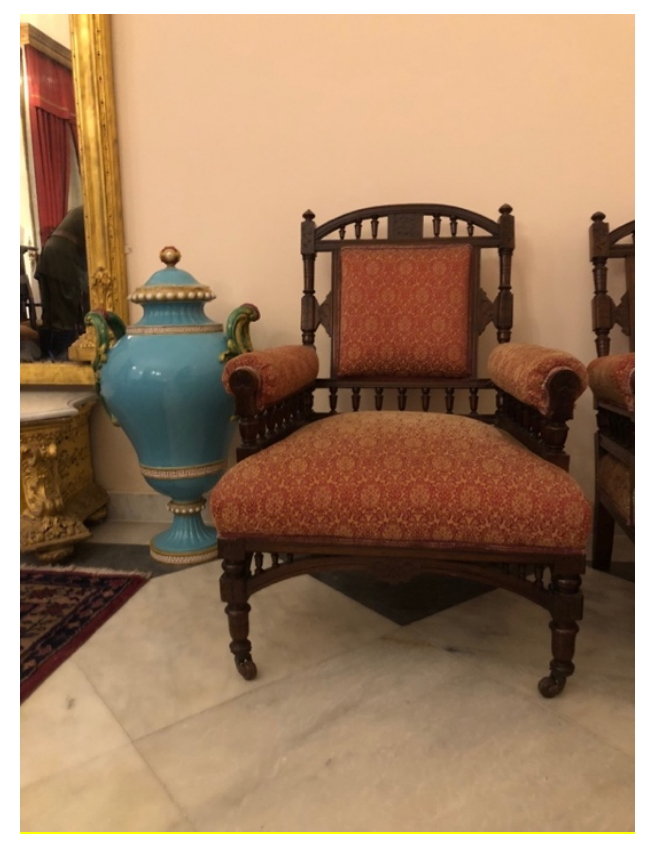

Figure 5. The Upholstered Chair (2001) in the Meeting Room, Jacquard Weaving Technique, Photographed by the author (2019), Courtesy of İzmir Atatürk House Museum. 
As mentioned before, modern brocades and velvets made in Turkey were affected by the Italian style (Peck, 2014, p. 143). Accordingly, the effects of the European pattern can be observed on the Turkish upholstery. In fact, textile furnishings can give a stylish, traditional and also a modern look to any décor (RamsamyIranah and Budhai, 2013, p. 286). It is possible to see the combination of different cultures like in these samples. National identity reflects on the design and production of the furniture (Avery, 2007, p. 71). The following part gives an answer to the first of the two above-mentioned research questions. Do they (nonoriginal textiles) influence the spirit of national or personal taste?

The textiles in question do not reflect the nation's identity and the taste of its founder. It is because the modernization with the foundation of the Republic, as a significant decision, caused people to question modernism and tradition. This decision was in the direction of moving away from the past (Yasa Yaman, 2013 , p. 80). Therefore, we cannot talk about the traditional elements in the early Republic period. The colors, patterns and motifs of the fabrics examined in this study do not represent the early Republic period or the pre-Republic period. In order to discuss the representations of the period between 1920 and 1938, it is necessary to consider the effects of Art Deco or Neo-Classicism on the fabrics as it is with the Western effect on the furniture. For example, "Selahattin Refik designed the study room for Atatürk between 1929 and 1930, which is on display in the Atatürk House Museum. The furniture design, bearskin, color selections and the polygonal form of the room reflect the Art Deco style". This information, which we obtained from the previous publications, proves that the Art Deco style was effective at that time. As seen in the publications of that period, all the interior architecture and decoration at that time was considered to be in connection with the modern way of life (Yasa Yaman, 2013). If the examples of this way of life do not reflect that period, what do the furnishing textiles look like in the early Republic period? It is necessary to analyze the examples of Art Deco, which was an effective art movement of the period.

Art Deco refers symbolically or clearly to electricity, mechanization, and transportation. These three words are associated with the discourse of modernity in the Republic of Turkey (Turan, 2010). Art deco plays an important role in the formation of textiles and textile pattern designs as well as the interior designs like in the examples of the dining rooms, chairs, walls, tables and windows (Dowdy, 2005, p. 61).

Floral and animal motifs were effective in the 1920s while flat and parallel lines were effective in the early 1930s. After the 1930s, bright-colored fabrics were replaced by plain fabrics (Yusufoğlu, 2014, p. 94). In the process that began with industrialization in the Republic period, the importance was given not only to production but also to design. Accordingly, Sümerbank Textile Factory was established in 1933 (Can and Özkartal, 2013, p. 124). The fact that the fabrics were made of valuable materials such as silk, gold and silver in the Ottoman period added monetary value to those fabrics (Önder, 1995, p. 330). Sümerbank fabrics, as opposed to the fabrics in the Ottoman period, were cheap, durable, quality and elegant fabrics with original patterns. They had small flowers, spots and geometric patterns as in the Art Deco style. Sümerbank fabrics and patterns, which represent the Republic period, were effective in all areas of the textile sector (Turkay, 2018). Why this effect could not be observed in the museum while it can be seen in the houses is another issue to be discussed.

Sümerbank fabrics were cotton and printed fabrics. It is possible to say that they were not preferred in the house museums because most of the upholstery fabrics in the museums of the Republic period were produced by weaving technique (Doğan, 2019, p. 36). However, it is not the techniques and materials but the patterns and motifs that can reflect the taste and identity of a nation. Therefore, Sümerbank patterns could have been woven with the weaving technique, so that they could have been adapted to the furniture made in the Art Deco style. Assuming that the fabrics had been reproduced according to this approach, would a reproduction furnishing textiles count historical textiles? Since the examples at issue are not original, they cannot be called historical textiles. However, if there were replicas, they could give us clues as to whether they reflect the spirit of that period.

\section{Conclusion}

In this article, the connection between the interior textiles in İzmir Atatürk House Museum and the early Republic Period have been examined. While this research mainly covers the interior textiles, the fact that the house museum belongs to Mustafa Kemal Atatürk, the founder of Turkish Republic, makes it more important. On the other hand, it is understood that the original textiles in this house museum could not be protected, preserved and recorded because of the restorations which have been made in it many times before. Based on this fact, the direction of the research has necessarily changed, and the upholstery fabrics, which are non-original, have been included in the study. According to the information obtained from the 
museum officials, the fabrics used in the house museum have been obtained from the companies in Ankara and the identity information of the experts has not been included in the records. For this reason, it is not exactly known according to which criteria these fabrics have been selected. From the information at issue, it is understood that these fabrics were not woven specially for the museum. Since this study is specific to İzmir Atatürk House Museum, a question may also come to mind as follows: Can there be any specific reason for these fabrics in İmir not to have been produced as replicas? This question can be answered with a further research to be done on the textiles in the other museums. In addition, such type of a research can only be possible by project-based studies, which will take a longer time, but not by a limited one. Depending on these findings, it is possible to say that the interior textiles in all the houses, where Mustafa Kemal Atatürk lived or which he used as headquarters, can be examined by a classification of originals, non-originals and replicas. Such studies can also contribute to the modern practice of indoor textiles.

The first question examined in the Methodology part of this study is: Do the non-original textiles influence the spirit of national or personal taste?. Fabrics used in house museums as memory objects are expected to represent a national identity and personal taste and to have an emotional bond with the people who lived there before. In order to reflect the spirit of the period, original or replica textiles, which are very close to the original ones, are expected to be used in these house museums. However, when the house museum for which this study has been carried out are examined, it is possible to say that these criteria and the expectations are not met. What is mentioned here can be summarized with Ames Kenneth's statement in his study Death in the Dining Room (1996), which is Conscious maybe the key word here. The second question examined in the Methodology part of this study is: What were the interior textiles in the early Republic period be like? It is possible to say that there is not an exact answer for this question because there are not any original fabrics. However, it can be suggested that the patterns similar to the ones on the SümerBank fabrics can be produced as mentioned in this article before, in addition to the production of replicas of the original fabrics in the other house museums.

Collective studies of the researchers from different fields are possible to make a great contribution to this field of study for the protection and introduction of the cultural heritage. It is also possible to say that historical textiles are important for the academicians, researchers, art historians and designers to be able to make a connection between today and the past and to transfer the new information to the next generation.

\section{References}

Akcan, E. (2012). Architecture in translation: Germany, Turkey, and the modern house. Durham: Duke University Press.

Aliağaoğlu, A. and Temurçin, K. (2004). Miras turizmi açısından Atatürk evleri. Erdem Dergisi, 14(41), pp. 119-138.

Andaç Güzel, T. and Efe, H. (2019). Cumhurbaşkanlığı Atatürk Müze Köşkü'ne ait bir iç mekân ve mobilya analizi örneği: Yeşil salon. International Social Sciences Studies Journal, 5(40), pp. 4108- 4116.

Aslanapa, O. (2005). Türk sanatı. İstanbul: Remzi Kitabevi.

Atasoy, S. (1999). Müzecilikten yansımalar. İstanbul: Anka Yayınları.

Avery, T. (2007). Furniture design and colonialism: Negotiating relationships between Britian and Australia, 1880-1901. Home Cultures, The Journal of Architecture, Design and Domestic Space, 4(1), pp. 69-92. doi: 10.2752/174063107780129680

Aydın, Ö. and Kavcı, E. (2005). İzmir Atatürk Müzesi deposunda bulunan cicim örneklerinin benzer yöre örnekleriyle karşılaştırılması. Sanat Dergisi, 0(8), pp. 35-46.

Bennet, T. (1995). The Birth of the museum, history, theory, politics. London: Routhledge.

Bici Nasir, E., Timuri Ş. and Gürel, Ö. M. (2020). Living rooms occupied: Narratives on the reconstextualization of the "Museum-Salon" practice in modern Turkish domesticity. Home Cultures, The Journal of Architecture, Design and Domestic Space, 16(1), pp. 63-92. doi: 10.1080/17406315.2019.1699739

Boltanski, C. (2019, June, 21). Ölüm, hafıza ve nesnelerin hayatı (Derya Yılmaz, Trans.). e-skop. Retrieved from: http://www.e-skop.com/skopbulten/pasajlar-olum-hafiza-ve-nesnelerinhayati/5173 
Bozdoğan, S. (2001). Modernizm ve ulusun inşası (Modernism and Nation Building). İstanbul: Metis Yayınları.

Can, Ö. and Özkartal, M. (2013). Endüstrileşmenin Cumhuriyet dönemi sonrası tekstil-moda tasarımında kimlik arayışına etkileri. Art-e Sanat Dergisi, 6 (11), 120-136.

Creswell, J. W., Hanson, W. E., Clark Plano, V. L. and Morales A. (2007). Qualitative research designs: Selection and implementation. The Counseling Psychologist, 35(2), pp. 236-264.

Damask. (1966). In Webster's Third New International Dictionary. Springfield: G.\& C. Merriam Company.

Doğaner, L. and Soydan, E. (2005). İzmir Atatürk Müzesi'ndeki mobilya aksesuarları olarak figürlü çiniler ve bir șömine. Sanat Tarihi Dergisi, 14(2), 49-73.

Erdem, T. (2007). Mobilya tarihine genel bir bakış ve Art Deco (Master thesis). İstanbul Kültür Üniversitesi Fen Bilimleri Enstitüsü, İstanbul.

Feryal, İ. (2001). Art Nouveau ve Art Deco mobilyalar. Antik Dekor Dergisi, 64.

Genim, S. (1994). Bir toplum için gelecek yaratmada müzelerin yeri. II. Müzecilik Semineri Bildirileri (16-18), İstanbul.

Gümüşer, T. (2018). Sevai fabrics in Konya Ethnography Museum. In M. Talas, A. Karataş and M. L. Emek (Eds.), Current Studies Over Sciences (pp. 218-231). Adıyaman: IKKSAD Publishing House.

Günhan, A. (2011). From houses to house museums: Architectural representation of different narrations (Master thesis). Middle East Technical University, Ankara.

Gürel, M. Ö. (2007). Domestic space, modernity, and identity: The Apartment in Mid-20th Century Turkey (Doctoral dissertation). University of Illinois, Urbana-Champaign.

Hansson, M. G. (2007). The private sphere: An emotional territory and its agent. New York: Springer-Verlag.

Hudales, J. (2010). Ethnographic objects as material culture and as cultural heritage: Ethnographic collections and exhibits in Slovenia until the first half of the 20th century. Nar. Umjet, 47(1), pp. 6989.

Hunter, G. L. (1918). Decorative Textiles. Philadelphia and London: J.B. Lippincott Company.

Hutton, S. S. (2004). Damask: An analysis of definitions. Pikes peak weavers guild. Complex Weavers Journal, $10(76)$, pp. 1-6.

Karaoğlu, S. A. (2011). İzmir Atatürk (Evi) Müzesi şöminelerinin koruma-onarım çalışmaları. Restorasyon ve Konservasyon Çalışmaları Dergisi, 7, 67- 72.

Karakuş, G. (2010). Handmade modernity postwar design in Turkey. In G. Adamson, G. Riello and S. Teasley (Eds.), Global Design History (p. 123), Londra: Routledge.

Kenneth, L. A. (1996). Death in the dining room \& other tales of Victorian culture. Philadelphia: Temple University Press.

Koşan, S. (1981). Atatürk evleri. Türkiyemiz Dergisi. 33, 1-10.

Kotb, M. R. (2014). Art Deco architectures as inspiration source in fashion design. International Journal of Science Commerce and Humanities. 2(3), pp. 1-17.

Madran, B. (1999). Müze türleri yeniden müzeciliği düşünmek (Tomur Atagök, Der.). İstanbul: Yıldız Teknik Üniversitesi Yayınları.

Marschall, S. (2019). Memory objects: Material objects and memories of home in the context of Intra-African mobility. Journal of Material Culture, pp. 1-17. doi: 10.1177/1359183519832630

Merriam, S. (1998). Cast study research in education: A qualitative approach. San Francisco: Jossey- Bass.

Mireles, S. (2010, February 8). How the history of damask fabric. Classroom. Retrieved from: http://www.ehow.com/about_6677037_history-damask-fabric.html

Mutlu, S., Aydın, B. \& Hünerel Sarıkaya, Z. (2017, November 09). Osmanlı saray kumaş desenlerinin giysi yüzey tasarımlarında kullanılması. 3nd International Congress on Political, Economic and Social Studies (ICPESS) (pp. 89-105), Bosnia. 
Mülayim, A. (2017). Art Deco mimarlı̆̆ı ve iç mekân tasarımına yansımaları. İleri Teknoloji Bilimleri Dergisi. $6(3), 1009-1026$.

Nielson, J. K. (2007). Interior textiles: Fabrics, application, and historic style. New York: John Wiley \& Sons.

Önder, M. (1995). Türkiye müzeleri. İstanbul: Türkiye İş Bankası Kültür Yayınları.

Peck, A. (Ed.) (2014). Intevowen globe. The worldwide textile trade, 1500-1800. The Metropolitan Museum of Art, NY. New Haven: Yale University Press.

Pinna, G. (2001). Introduction to historic museums. Museum International. 53(2), 4.

Ponsonby, M. (2011). Textiles and time: Reactions to aged and conserved textiles in historic houses open to the public in England and the USA. Textile History. 42(2). doi: 10.1179/174329511X13123634653901

Ramsamy-Iranah, S. and Budhai, N. (2013). Developing a new concept of reversible textile furnishing. International Journal of Home Economics (IJHE), 6(2), pp. 286-304.

Savaş, A. (2010). House museum: A new function for old buildings. METU JFA, 27(1), pp.139-160.

Shuang, T. and Lee, C. (2020). Curriculum based interactive exhibition design and family's learning experiences: a case study of the children's art museum in Taipei. Curator Journal of Museum, 63(1), pp. 83-98.

Stake, R. (1995). The art of case study research. London: Sage Publications.

Sönmez, Z. (1994, September 19). Avrupa'da uygulanan bazı örneklerle çağdaş müzecilik ve serbest sergileme. II. Müzecilik Semineri Bildirileri (101-103). İstanbul.

Tortora, G. and Johnson, I. (2013). The fairchild books: Dictionary of textiles. New York: Bloomsbury Publishing.

Tosun, B. Ç. and Özsu, C. A. (2014). Cumhuriyet dönemi Art Deco mobilya tasarımları: Selahattin Refik Sırmalı ve Atatürk'ün çalışma odası. Ankara Araştırmaları Dergisi, 2(2), 216- 235.

Turkay, B. (2018, April 23). Bir dönemin toplumsal eşitleyicisi Sümerbank. Manifold Press. Retrieved from: https://manifold.press/bir-donemin-toplumsal-esitleyicisi-sumerbank

Turan, G. (2010). Turkish furniture design in the 1930s: Responses to Art Deco in the early Republican Era. Furniture History, 46(1), 233-248.

Uras, G. (2003, May 04). Olayların içinden: Art Nouveau'dan Art Deco'ya. Milliyet.

Uz, S. (2015). Müze evler. Atatürk Dil Kültür ve Tarih Yüksek Kurumu. Retrieved from: https://www.ayk.gov.tr/wp-content/uploads/2015/01/UZ-Seden-M\%c3\%9cZE-EVLER.pdf

Wilson, S. C. (2007). Remembering and forgetting in the funerary architecture of Mustafa Kemal Atatürk: The construction and maintanence of national memory (Doctoral dissertation). Middle East Technical University, Ankara.

Yasa Yaman, Z. (2013). Bauhaus ve söylemleştirilen iç mekân anlayışı: Yeni yaşam, yeni dekorasyon, yeni mobilya. U. Şunmu (Ed.), Erken Cumhuriyet döneminde mobilya içinde (81-100), TMMOB İç Mimarlar Odası, Ankara.

Yeager, J. \& Teter-Justice, L. K. (2000). Textiles for residential and commercial interiors (2nd ed.). New York: Fairchild Publications.

Yetkin, Ş. (1993). Türk kumaş sanatı. M. Önder (Ed.), Başlangıcından bugüne Türk sanatı içinde, Ankara: Türkiye İş Bankası Yayınları.

Young, L. (2007). Is there a museum in the house? Historic houses as a species of museum. Museum Management and Curatorship, 22(1), pp. 59-77. doi: 10.1080/09647770701264952

Zainal, Z. (2007). Case study as a research method. Jurnal Kemanusiaan, 5(1), pp. 1-6. 